\title{
FORUM
}

\section{The Mystery of Captain Lane's Compass}

\author{
W. E. May
}

Charles Henry Lane was born at Hereford about the year 1754 and at the age of 17 joined the Buckingham, 70 guns, Captain John Symons. In this ship he went to India, spending about four years in her, the first two as able seaman and the second two as midshipman. Returning home he joined the Enterprize, 28, Captain Sir Thomas Rich, spending about two years in her in the Mediterranean. Of these the first three months were as able seaman and the rest as midshipman.

In July 1777 he successfully passed his examination for lieutenant and in September received his commission to the Royal Oak, 74, initially as 5 th lieutenant but rising to 3 rd before, in April 1778 , he was appointed ist lieutenant of the Surprize, 28, Captains Robert Linzee and later Samuel Reeve. In that ship he served just over three years, each year making a voyage to Newfoundland and back from about June to November. While in those waters on the third voyage he was transferred to the Portland, 50, Captain James Luttrell. Then in September 1782 Vice-Admiral John Campbell promoted him to Commander and placed him in command of the sloop St Johns, which had been purchased locally. Exactly a year later the St Johns was paid off and Commander Lane returned home and was placed on half-pay.

What happened to Commander Lane during the time that he was unemployed is not known, but in September 1788 he wrote letters to the Admiralty and to the Navy Board stating that he had constructed a compass 'on a different principle from any hitherto made use of ' and asking that it might be given a trial. In the letter to the Navy Board he described the 'different principle'; this letter was forwarded by the Board to the Admiralty and has unfortunately disappeared.

It was decided that the compass should be tried in the Hebe, 38, Captain Edward Thornborough, employed in the English Channel and the report, forwarded from her in October 1789 , is of considerable interest. Captain Thornborough wrote:

On the I $5^{\text {th }}$ Day of December last, when running before the wind between Portland, and the Start, with a very Heavy following sea, which caused the Ship to have great motion, I then observed the Vibration of Captn Charles Hy Lanes Compass, was only half a Point, when the Common Ships Compass Vibrated two Points and a half each way. This was the only severe Gale I had to make any good trial of it. In common weather its Vibration is the same as the Ships Compass, but in very Light Wind, Smooth Water, \& Calms when the common Compass, requires to be often touched, to make it Traverse, the Compass of Captn Charles H. Lane does not require touching, as it moves with the Ship.

But I am of opinion that the Compass should be tried on board a Ship bound a Cross the Western Ocean, where I think it would be found far superior to our common Compasses. 
It was decided to take Captain Thornborough's advice and orders were issued for the compass to be put on board the Gorgon, 44, Lieutenant William Harvey, destined to go to Australia. However in 1790 , before she was ready for sea, relations with Spain became strained and in the consequent mobilization the departure of the Gorgon was delayed. The alarm was over by November and in that month Lane was promoted to Captain but given no appointment.

What now happened to Captain Lane's compass is obscure. In January 179 I the Admiralty wrote to the Navy Board implying that it had been transferred from the Gorgon to the Queen Charlotte, roo, Captain H. C. Christian, flagship of Sir R. Curtis, and giving instructions that it should now be sent to the Niger, 32 , Captain George Berkeley, under orders for the West Indies. In spite of the most diligent search I have failed to find any record of the Navy Board having done anything about this instruction. Apparently it was ignored. Perhaps those who should have handled the matter feared that the compass had been lost in its wanderings between the Hebe, the Gorgon and the Queen Charlotte and hoped that if they did nothing it would eventually be forgotten. In any case we hear no more about it. It was a most regrettable failure.

One would have expected Captain Lane to have done something to obtain further trials for his compass, but apparently he lost interest in it. It was not that he was away from England or that he was too busy. At one time he was employed in the regulating service, at another he was conducting an enquiry into possible landing places for the enemy in Cornwall, and then for several years he commanded accommodation hulks for French prisoners of war. In 1805 he was made Commissioner at Barbados, subsequently being transferred to Antigua where he is believed to have died in 1807 .

We are left with the question; what was the secret of the design of Lane's compass which made it so steady in heavy weather? At this date a naval compass card was made with a single heavy flat bar needle. It was not generally recognized that when a ship was rolling such a compass card had a tendency to turn so that the needle would approach the plane of the roll. Of course the magnetic influence would prevent it doing so completely but a deviation inevitably resulted, whose magnitude depended upon the angle between the direction of roll and the magnetic meridian, and on the violence of the motion of the ship. It is possible that Lane had discovered this and had fitted his compass with two needles, though it is unlikely that he would have found out the law governing their optimum distance apart.

About the year 1782 Christian Carl Loos published in Denmark the description of a new compass card which had four very light needles and a cross-bar which balanced it. By this means he obtained a constant moment of inertia about all horizontal axes, thus eliminating the effect of rolling, and also produced a light card which caused less friction and consequent wear upon the pivot. It must have been a most satisfactory compass and it was a misfortune that it was not more widely publicised. I have failed to find any record of its ever being tried in this country.

There is a possibility that Captain Lane had, during his period of half-pay, seen the compass card of Loos and had based his own upon it. It is an intriguing possibility, but it is a pity that I have been unable to find the letter in which were stated the principles on which he worked. 